\title{
A Full Circle Appraisal on Emotional Intelligence
}

\author{
Murugesan Kaliyaperumal $^{1}$, Srinivasan Padmanaban ${ }^{2, *}$ \\ ${ }^{1}$ Department of Education, Tamil University, Thanjavur, India \\ ${ }^{2}$ School of Education, Central University of Tamil Nadu, India \\ *Corresponding author: seenuthilaka@yahoo.com
}

Received November 14, 2018; Revised December 17, 2018; Accepted January 11, 2019

\begin{abstract}
This study is about the construction of the Emotional Intelligence $360^{\circ}$ Tool. The method is a normative method with survey technique. Daniel Goleman's dimensions were used to construct the items. The sample is selected from students of higher secondary schools. Four subscales such as self-view, teacher view, peer view, and parent view make up Ei $360^{\circ}$ Tool. Reliability, validity was measured, norms of the tool were established, and the scoring procedure was given.
\end{abstract}

Keywords: emotional intelligence, appraisal, $360^{\circ}$ tool

Cite This Article: Murugesan Kaliyaperumal, and Srinivasan Padmanaban, "A Full Circle Appraisal on Emotional Intelligence.” American Journal of Educational Research, vol. 7, no. 1 (2019): 49-57. doi: 10.12691/education-7-1-8.

\section{Introduction}

At present, the concept of emotional intelligence is being applied in various fields like Education, Medical, Commerce, Management, Business, Industries, and so on. Emotional Intelligence is, perceiving self and others emotions, understanding them and use in our thought and action. Following are some of the definitions of emotional intelligence given by renowned psychologists. Salovey and Mayer (1999) [1] conceptualized the term emotional intelligence as the subset of social intelligence that involves the ability to monitor one's own and others feelings and emotions, discriminate among them and to use information to guide one's thinking and action.

Bar-On (1997) [2] Emotional Intelligence is an array of emotional, personal and social abilities which influence one's overall ability to cope effectively with environmental demands and pressure. Murugesan and Srinivasan (2017) [3] Emotional Intelligence is “one's ability to understand one's own and other feelings, recognizing and regulate one's personal and social competencies”. Emotional intelligent is an intelligent to manage the emotions and it leads to peace and successful life. According to Goleman (1998) [4], Emotional intelligence is $80 \%$ responsible for success in life and intelligence is only 20\%. Emotional intelligence is a proper and precise key for manage one's emotions.

\section{Background of the Study}

The past several years, it is believed that success in life or at work place depends upon the individual level of intelligence or intelligence quotient as reflected in an individual's academic achievement, examination passed, mark obtained etc. Now, research on emotional intelligence has revealed that EQ is the most important determinant of professional and person success in life. Because, emotional intelligence is a powerful trait which helps a person build relationships, using the knowledge of different behavior types, promote a leadership capabilities, capacity to manage the emotion, ability to function in a group and solve the everyday problems. It leads the peaceful life and makes a successful life.

If a person is affected by an emotion, it is contagious. Normally, in real classroom the student's emotions affects the teacher as well as the teacher's emotions affects the students [5].

The emotional outbursts become an evil power to disturb the Peace in society. If the emotions are not managed by a person, it will affect physically and mentally. A person should know that how to manage emotions and how they affect them self and others, Murugesan and Srinivasan (2017) [6]. A person feelings cannot be observed directly by others, they can also be inferred from his/her overt behavior and verbal report of his/her introspection. To produce on emotion, a situation must be related to stimulus past experience. In recent years, emotional outburst disturbs the society largely.

Many educational institutions are trying to find out the solutions to solve the emotional problems, before solving emotional problems of students one should measure the emotional intelligence of students. There are several tools on Emotional Intelligence. These tools measures emotional intelligence from one view and hence a person's emotional intelligence from many angle is not seen. Full-fledged aspect of emotional intelligence can be said as $360^{\circ}$. Based on the review of related literature no specific tool is available in India to measure Emotional Intelligence of higher secondary school students in $360^{\circ}$. Hence there is a need to construct a $360^{\circ}$ tool to measure the Emotional Intelligence of higher secondary school students. 
Table 1. Goleman's Model of Emotional Intelligence

\begin{tabular}{|l|l|l|l|l|}
\hline Self Awareness & Self regulation & Motivation & Empathy & Social skills \\
\hline Emotional awareness & Self control & Achievement drive & Understanding others & Influence \\
\hline Accurate self-assessment & Trustworthiness & Commitment & Developing others & Communication \\
\hline Self confidence & Conscientiousness & Initiative & Service orientation & Conflict management \\
\hline & Adaptability & Optimism & Leveraging diversity & Leadership \\
\cline { 2 - 4 } & Innovation & Political awareness & Change catalyst \\
\cline { 2 - 4 } & & & Building bonds \\
& & & Collaboration and cooperation \\
\hline
\end{tabular}

\subsection{Goleman’s Emotional Intelligence Model}

Goleman (1998) [4] is popularly known for his best seller emotional intelligence: 'Why it is more than IQ' and 'Working with emotional intelligence'. Table 1 depicts Goleman's five domains of emotional intelligence along with its twenty five components. For constructing the Ei 360 degree tool Goleman's competencies were used 20 competencies.

\section{Need for $360^{\circ}$ Tool in EI}

Generally, Most of the psychological traits are measured by giving the tool to the subject and the responses were analyzed and interpreted. The measures may be highly subjective. For reducing the subject bias, the tool might be given to the peers / relatives / boss of the subject. It may reduce the biasness in the measurement. According to Lapsinger (2009) [7] 360 degree feedback process involves colleting perceptions about a person's behavior and the impact of that behavior from the person's boss or bosses, direct reports, colleagues, fellow members of project teams, internal customers, and suppliers. Other names for 360 feedbacks are multi-rater feedback, multi-source feedback, full-circle appraisal, and group performance review.

Five reasons for using 360 degree feedback are as follows; How am I doing; it can be used as a guide for continuous improvement; it can help leaders check the validity of their self-perceptions; it ensures that leaders view themselves realistically and it encourages people to invest in the effectiveness of leaders [8].

According to Lapsinger (2009) [5], 360 degree process is a tool that supports development related to succession planning. 360 degree tool can be used to determine the development needs of an individual. According to Turkel (2008) [9], 360 degree feedback is defined as a method where by a person is provided with feedback from others such as direct reports, peers, and managers regarding their performance.

One's strength and weakness affect them and as well as others, one is in need of different kinds of feedback to be progressive in the career. Based on this concept, so the constructors have made an attempt to measure the Emotional intelligence in unbiased manner. The constructors constructed Ei $360^{\circ}$ tool for measure Ei of school students in $360^{\circ}$ view. Figure 1 shows the concept of $360^{\circ}$ tool for measures Ei of school students in $360^{\circ}$ view.

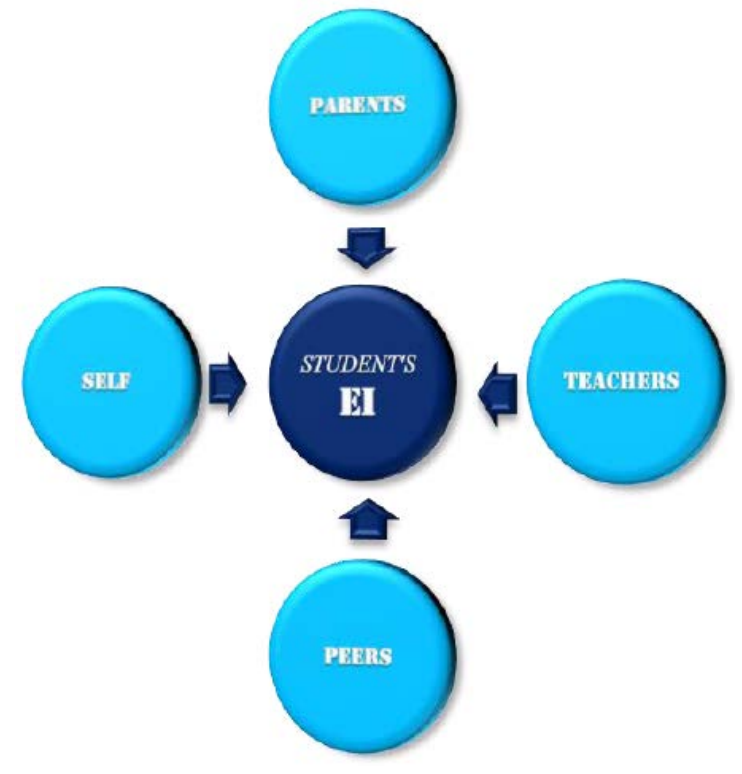

Figure 1. The Concept of $360^{\circ}$ Tool

\section{Operational Definition of the Keywords}

The constructors has defined the key words of the study as follows

\section{Construction}

Items of the measurement are developed based on theory, research, and experience in systematic plan and procedure. In the present study, the term of construction indicates specially the construction of Ei $360^{\circ} \mathrm{Tool}$.

\subsection{Standardization}

Standardization is a process of establishing validity, reliability, Norms and usability for $\mathrm{Ei} 360^{\circ}$ Tool.

\subsection{Emotional Intelligence}

Emotional Intelligence is "One's ability to understand one's own and other feelings, recognizing and regulate one's personal and social competencies”.

\section{3. $360^{\circ}$ Tool}

$360^{\circ}$ Tool provides the view of a particular trait of a person from all possible angles such as self, parent, peers and teachers. 


\section{Objectives of the Study}

The following are the objectives of the present study.

- To standardize the Ei3600 Tool for higher secondary school students.

- To establish the reliability quotients, validity quotients and Norms of constructed Ei3600 Tool.

- To find out the relationship among the sub- scales of Ei3600 Tool such as,

- Self

- eacher's view

- Peer's view

- Parent's view.

\section{Method of Investigation of the Study}

The constructor has selected normative method with survey method for collecting data.

\subsection{Location}

In research, location is an identification of the geographical area where the researcher selects the population and sample for conducting the research. The constructors have selected the sample in Thanjavur, Tamilnadu, India.

\subsection{Population}

For fulfilling the objectives of the study, the tool constructors have selected population as higher secondary school students and their respective Parents, Teachers and Peers.

\subsection{Sample of the Study}

The sample has been selected in three stages. In first stage, 3 higher secondary schools were selected by using simple random sampling technique.

In second stage, the 100 higher secondary students (age group 15 to 18) were randomly selected by using simple random sampling technique.

In the last stage of sampling, the respective parents (both educated and uneducated \& both rural and urban), peers and class teachers of the students were selected by using purposive sampling technique.

\subsection{Tool of the Study}

Tool is very essential instrument to measure or assess or evaluate any type of variables. In social science studies, the researchers should pay a great attention in searching or constructing a tool which it may be constructed or it available in readymade mode. The precise in measurement is directly depends on objectivity of the measuring tool. So the constructors have constructed Ei $360^{\circ}$ Tool for assessing the Emotional Intelligence of higher secondary school student in unbiased manner.

\section{Construction of the Ei360 ${ }^{\circ}$ Tool}

A quality research instrument alone helps a researcher to obtain valid information from the respondents.

Reducing measuring bias and accuracy in measurement, the Ei360 $0^{\circ}$ Tool has been constructed in feedback forms. It consisted with four different sub-scales such as self (student), teachers view, peers view and parent's view of $\mathrm{Ei} 360^{\circ}$ Tool. The following procedures have been followed by the constructors for constructing the Ei $360^{\circ}$ Tool.

\subsection{Construction of Ei360 ${ }^{\circ}$ Tool Statements}

After selecting the dimension and its competencies for the Ei $360^{\circ}$ Tool, the statements were constructed which reflects the meaning of the dimensions of Daniel Goleman. Initially self view sub scale is constructed. After reliability and validity measures, items were given in III person to teacher, peer and parents. The constructors have decided to measure Emotional Intelligence in five point descriptive rating scale such as, always, usually, sometimes, rarely and never.

The preliminary draft of Ei $360^{\circ}$ Tool was constructed with 100 items. Single dimensional was constructed already by constructors. But going for $360^{\circ}$ tool would be letter and hence this study. Dimension wise item description of Ei360 $0^{\circ} \mathrm{Tool}$ is given below Table 2.

Table 2. Dimension wise Items on $\mathrm{Ei}^{360^{\circ}}{ }^{\mathrm{T}} \mathrm{Tool}$

\begin{tabular}{|c|l|c|}
\hline S.No. & Domains of Emotional Intelligence & Number of Items \\
\hline 1 & Self-Awareness & 15 \\
\hline 2 & Social Awareness & 15 \\
\hline 3 & Self-Management & 30 \\
\hline 4 & Relationship Management & 40 \\
\hline Total & & 100 \\
\hline
\end{tabular}

\subsection{Experts’ Opinion}

The preliminary draft was sent to the panel of experts. Above form of Ei $360^{\circ}$ Tool of 100 statements was sent to faculties of Education for further recommendations.

The preliminary draft was finalized with 75 items out of 100 items. A statistical procedure called content validity ratio and it's were adopted to reduce items. According to Lawshe (2010) [10] developed a formula termed the content validity ratio as follows:

$$
C V R=(N e-N / 2) /(N / 2)
$$

Where,

CVR- Content validity ratio,

$\mathrm{Ne}$ - Number of subject matter experts (SME) indicating "Essential",

$\mathrm{N}$ - Total number of SME experts.

\subsection{Pre-Pilot Study of the Ei $360^{\circ}$ Tool}

The pre-pilot tryout was carried out keeping in mind the following objectives: to modify the instruction of the tool if required and to modify the statement if students find it ambiguous.

The pre tryout has conducted to reduce the ambiguousness in the statements. The tool of Ei $360^{\circ} \mathrm{Tool}$ has given to the higher secondary students and they are requested to provide feedback. If the students had doubts, they are 
clarified and re modified. Ambiguous statements were removed by the investigator. The items were reduced 75 to 65.

\subsection{Pilot Study of the Ei $360^{\circ}$ Tool}

The objective of the pilot study is to select statements for final form on the basis of statistical analysis. The pilot study was conducted with the sample of 300 higher secondary students of Thanjavur district.

\subsection{Item Analysis}

For item analysis, the questionnaire were scored and organized in descending order. The top $27 \%$ of were selected as upper group and bottom $27 \%$ were selected as lower group. For item selection the following $t$ test formula was used.

The following formula was used (Edwards, 1957) [11] to calculate value of each items.

$$
t=\frac{\bar{X}_{H}-\bar{X}_{L}}{\sqrt{\frac{S_{H}^{2}}{n_{H}}+\frac{S_{L}^{2}}{n_{L}}}}
$$

Where
$\bar{X}_{H}=$ the mean score on a given statement for the high group

$\bar{X}_{L}=$ the mean score on a given statement for the low group

$S_{H}^{2}=$ the variance of the distribution of response of the high group of the statement.

$S_{L}^{2}=$ the variance of the distribution of response of the low group of the statement.

$n_{H}=$ the number of subjects in the high group

$n_{L}=$ the number of subjects in the low group

\subsection{Pre Final Form of the Ei360 ${ }^{0}$ Tool}

The pre final form of the Ei $360^{\circ}$ Tool was developed with 62 items which are selected of it $t$ value. The $t$ values of the item having 1.75 and higher were selected for pre final form $\mathrm{Ei}_{360^{\circ}}$ Tool. The 62 statements selected for the pre final form of the Ei $360^{\circ}$ Tool. After Selecting 62 items, the other subscales such as, teacher's view, peer's view, and parent's view have constructed with the same meaning of the items as in Self view with its modification of the subject (first person, second person and third person). Table 3 shows that dimension and sub dimension wise selected items of Ei $360^{\circ}$ Tool.

Table 3. Dimension and sub dimension wise Selected Items on Ei360 ${ }^{\circ}$ Tool

\begin{tabular}{|c|c|c|c|c|c|c|c|}
\hline 产 & Competencies & $\begin{array}{c}\text { Item } \\
\text { Number }\end{array}$ & Item type & $\begin{array}{c}\text { Item status by } \\
\text { content validity } \\
\text { ratio }\end{array}$ & $\begin{array}{l}\text { Item status by } \\
\text { pre pilot study }\end{array}$ & $\begin{array}{c}\text { Item status by } \\
\text { 't' value }\end{array}$ & $\begin{array}{c}\text { New item } \\
\text { number for } \\
\text { pre final } \\
\text { form } \\
\end{array}$ \\
\hline \multirow{15}{*}{ 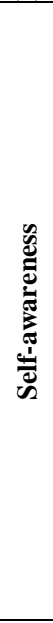 } & \multirow{5}{*}{$\begin{array}{c}\text { Emotional } \\
\text { self-awareness }\end{array}$} & 1 & Positive & Selected & Selected & Selected & 1 \\
\hline & & 2 & Positive & Selected & Selected & Selected & 2 \\
\hline & & 3 & Negative & Not Selected & - & - & - \\
\hline & & 4 & Positive & Selected & Not Selected & - & - \\
\hline & & 5 & Positive & Selected & Selected & Selected & 3 \\
\hline & \multirow{5}{*}{$\begin{array}{c}\text { Accurate } \\
\text { self-assessment }\end{array}$} & 6 & Negative & Not Selected & - & - & - \\
\hline & & 7 & Positive & Selected & Selected & Selected & 4 \\
\hline & & 8 & Positive & Selected & Not Selected & - & - \\
\hline & & 9 & Positive & Selected & Selected & Selected & 5 \\
\hline & & 10 & Positive & Selected & Selected & Selected & 6 \\
\hline & \multirow{5}{*}{ Self confidence } & 11 & Positive & Not Selected & - & - & - \\
\hline & & 12 & Negative & Selected & Selected & Selected & 7 \\
\hline & & 13 & Positive & Selected & Selected & Selected & 8 \\
\hline & & 14 & Negative & Not Selected & - & - & - \\
\hline & & 15 & Positive & Selected & Selected & Selected & 9 \\
\hline \multirow{15}{*}{ 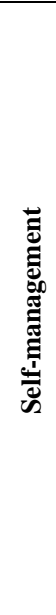 } & \multirow{5}{*}{ Self-control } & 16 & Positive & Selected & Selected & Selected & 10 \\
\hline & & 17 & Negative & Selected & Selected & Not Selected & - \\
\hline & & 18 & Positive & Selected & Selected & Selected & 11 \\
\hline & & 19 & Positive & Selected & Selected & Selected & 12 \\
\hline & & 20 & Negative & Selected & Selected & Selected & 13 \\
\hline & \multirow{5}{*}{ Trustworthiness } & 21 & Positive & Not Selected & - & - & - \\
\hline & & 22 & Positive & Selected & Selected & Selected & 14 \\
\hline & & 23 & Positive & Selected & Selected & Selected & 15 \\
\hline & & 24 & Negative & Selected & Not Selected & - & - \\
\hline & & 25 & Positive & Selected & Selected & Selected & 16 \\
\hline & \multirow{5}{*}{ Conscientiousness } & 26 & Positive & Selected & Selected & Selected & 17 \\
\hline & & 27 & Positive & Selected & Selected & Selected & 18 \\
\hline & & 28 & Positive & Not Selected & - & - & - \\
\hline & & 29 & Positive & Selected & Selected & Selected & 19 \\
\hline & & 30 & Negative & Selected & Not Selected & - & - \\
\hline
\end{tabular}




\begin{tabular}{|c|c|c|c|c|c|c|c|}
\hline 量 & Competencies & $\begin{array}{c}\text { Item } \\
\text { Number }\end{array}$ & Item type & $\begin{array}{c}\text { Item status by } \\
\text { content validity } \\
\text { ratio }\end{array}$ & $\begin{array}{l}\text { Item status by } \\
\text { pre pilot study }\end{array}$ & $\begin{array}{l}\text { Item status by } \\
\text { ' } t \text { ' value }\end{array}$ & $\begin{array}{c}\text { New item } \\
\text { number for } \\
\text { pre final } \\
\text { form } \\
\end{array}$ \\
\hline & \multirow{5}{*}{ Adaptability } & 31 & Positive & Selected & Selected & Selected & 20 \\
\hline & & 32 & Positive & Selected & Selected & Selected & 21 \\
\hline & & 33 & Positive & Selected & Not Selected & - & - \\
\hline & & 34 & Negative & Not Selected & - & - & - \\
\hline & & 35 & Positive & Selected & Selected & Selected & 22 \\
\hline & \multirow{5}{*}{$\begin{array}{c}\text { Achievement } \\
\text { drive }\end{array}$} & 36 & Positive & Selected & Selected & Selected & 23 \\
\hline & & 37 & Positive & Selected & Selected & Selected & 24 \\
\hline & & 38 & Positive & Selected & Selected & Selected & 25 \\
\hline & & 39 & Positive & Selected & Selected & Not Selected & - \\
\hline & & 40 & Negative & Not Selected & - & - & - \\
\hline & \multirow{5}{*}{ Initiative } & 41 & Positive & Selected & Selected & Selected & 26 \\
\hline & & 42 & Positive & Selected & Selected & Selected & 27 \\
\hline & & 43 & Negative & Not Selected & - & - & - \\
\hline & & 44 & Positive & Selected & Selected & Selected & 28 \\
\hline & & 45 & Negative & Selected & Selected & Selected & 29 \\
\hline \multirow{15}{*}{ 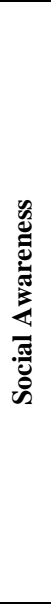 } & \multirow{5}{*}{ Empathy } & 46 & Positive & Selected & Selected & Selected & 30 \\
\hline & & 47 & Negative & Not Selected & - & - & - \\
\hline & & 48 & Positive & Selected & Selected & Selected & 31 \\
\hline & & 49 & Positive & Selected & Selected & Selected & 32 \\
\hline & & 50 & Positive & Not Selected & - & - & - \\
\hline & & 51 & Positive & Selected & Selected & Selected & 33 \\
\hline & & 52 & Positive & Selected & Selected & Selected & 34 \\
\hline & Service & 53 & Negative & Not Selected & - & - & - \\
\hline & & 54 & Positive & Selected & Selected & Selected & 35 \\
\hline & & 55 & Negative & Selected & Selected & Selected & 36 \\
\hline & & 56 & Positive & Selected & Selected & Selected & 37 \\
\hline & & 57 & Positive & Not Selected & - & - & - \\
\hline & Organizational & 58 & Positive & Selected & Selected & Selected & 38 \\
\hline & & 59 & Negative & Selected & Not Selected & - & - \\
\hline & & 60 & Positive & Selected & Selected & Selected & 39 \\
\hline & & 96 & Positive & Selected & Selected & Selected & 61 \\
\hline & & 97 & Positive & Not Selected & - & - & - \\
\hline & Developing others & 98 & Positive & Selected & Selected & Selected & 62 \\
\hline & & 99 & Negative & Selected & Not Selected & - & - \\
\hline & & 100 & Positive & Not Selected & - & - & - \\
\hline & & 61 & Positive & Not Selected & - & - & - \\
\hline & & 62 & Positive & Selected & Selected & Selected & 40 \\
\hline & Influence & 63 & Negative & Selected & Not Selected & - & - \\
\hline & & 64 & Positive & Selected & Selected & Selected & 41 \\
\hline & & 65 & Positive & Selected & Selected & Selected & 42 \\
\hline & & 66 & Positive & Not Selected & - & - & - \\
\hline$\ddot{\Xi}$ & & 67 & Positive & Selected & Selected & Selected & 43 \\
\hline छ & Communication & 68 & Negative & Not Selected & - & - & - \\
\hline$\stackrel{\Xi}{\Xi}$ & & 69 & Positive & Selected & Selected & Selected & 44 \\
\hline$\sum^{\pi}$ & & 70 & Negative & Selected & Selected & Selected & 45 \\
\hline 刍 & & 71 & Positive & Selected & Not Selected & - & - \\
\hline 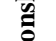 & Conflict & 72 & Positive & Selected & Selected & Selected & 46 \\
\hline 劳 & management & 73 & Negative & Not Selected & - & - & - \\
\hline 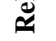 & & 74 & Negative & Selected & Selected & Selected & 47 \\
\hline & & 75 & & Selected & Selected & Selected & 48 \\
\hline & & 76 & Negative & Not Selected & - & - & - \\
\hline & & 77 & Positive & Selected & Selected & Selected & 49 \\
\hline & Leadership & 78 & Positive & Selected & Selected & Selected & 50 \\
\hline & & 79 & Positive & Not Selected & - & - & - \\
\hline & & 80 & Positive & Selected & Selected & Selected & 51 \\
\hline & & 81 & Positive & Selected & Selected & Selected & 52 \\
\hline & & 82 & Positive & Not Selected & - & - & - \\
\hline & Change catalyst & 83 & Positive & Selected & Selected & Selected & 53 \\
\hline & & 84 & Negative & Selected & Not Selected & - & - \\
\hline & & 85 & Positive & Selected & Selected & Selected & 54 \\
\hline
\end{tabular}




\begin{tabular}{|c|c|c|c|c|c|c|c|}
\hline مَّ & Competencies & $\begin{array}{c}\text { Item } \\
\text { Number }\end{array}$ & Item type & $\begin{array}{c}\text { Item status by } \\
\text { content validity } \\
\text { ratio }\end{array}$ & $\begin{array}{l}\text { Item status by } \\
\text { pre pilot study }\end{array}$ & $\begin{array}{c}\text { Item status by } \\
\text { 't' value }\end{array}$ & $\begin{array}{c}\text { New item } \\
\text { number for } \\
\text { pre final } \\
\text { form } \\
\end{array}$ \\
\hline & \multirow{5}{*}{ Building bonds } & 86 & Positive & Not Selected & - & - & - \\
\hline & & 87 & Positive & Selected & Selected & Selected & 55 \\
\hline & & 88 & Positive & Not Selected & - & - & - \\
\hline & & 89 & Positive & Selected & Selected & Selected & 56 \\
\hline & & 90 & Positive & Selected & Selected & Selected & 57 \\
\hline & \multirow{5}{*}{$\begin{array}{l}\text { Teamwork \& } \\
\text { collaboration }\end{array}$} & 91 & Negative & Selected & Selected & Selected & 58 \\
\hline & & 92 & Positive & Selected & Selected & Not Selected & - \\
\hline & & 93 & Positive & Selected & Selected & Selected & 59 \\
\hline & & 94 & Positive & Not Selected & - & - & - \\
\hline & & 95 & Positive & Selected & Selected & Selected & 60 \\
\hline
\end{tabular}

\subsection{Reliability, Validity and Norms of the Ei360 ${ }^{\circ}$ Tool}

A good tool should possess the qualities such as validity, reliability, norms etc. the investigator found the validity and reliability of the Ei $360^{\circ}$ Tool and Norms has established.

\subsection{Reliability}

In the present study the reliability of the sub scales ofEi $360^{\circ}$ Tool was found with the use of test retest method, split half method and internal consistencies method. The reliabilities of the Ei $360^{\circ}$ Tool were calculated.

\subsection{Validity}

It is always related to the specific objectives or purpose of the test. It is simply called as "the degree of excellence in measurement”. The following validities were found against $\mathrm{Ei}^{\circ} 60^{\circ}$ Tool.

\subsection{Face Validity}

It is nothing but the readiness of the tool to measure, the sub scale of Ei $360^{\circ}$ Tool were sent to the panel of subject experts. The suggestions things were made in the tool by the investigator.

\subsection{Content Validity}

The Ei $360^{\circ}$ Tool includes all contents of Emotional Intelligence which has been given as dimensions in the Ei $360^{\circ}$ Tool and they have been derived from the Daniel Goleman and Richard Boyatiz model of Emotional Intelligence. The subject experts suggested that all competencies of emotional intelligence were covered in the form of items. Content validity ratio of the Ei $360^{\circ}$ Tool were calculated.

\subsection{Construct Validity}

Dimension and its items were constructed with the help of Daniel Goleman theory and validated the tool by a systematic procedure. The item selection is based on the ' $t$ ' value of 1.75 . the $t$ values of the Ei $360^{\circ}$ Tool were calculated.

\subsection{Concurrent Validity}

Concurrent validity refers to the degree to which the operationalization correlates with other measures of the same construct that are measured at the same time. For finding concurrent validity, the $\operatorname{Ei}_{360^{\circ}}$ Tool was administered with the standardized tool of Anukool Hyde et al (2002) [12]. The scale has ten factors, these are self-awareness, empathy, self-motivation, emotional stability, managing relations, integrity, self-development, value orientation, commitment and altruistic behavior. The reliability of the Anukool Hyde et al EI scale was found to be 0.88 and the scale was administered the sample of 200 subject, the reliability index was calculated which show high validity on account of being 0.93 . The inter related correlation were found and the concurrent validity of the Ei360 ${ }^{\circ}$ Tool were calculated.

\subsection{Intrinsic Validity}

The intrinsic of the validity is also called as internal validity or numerical validity which refers the internal correlation of items of the tool. The intrinsic validity of the $\mathrm{Ei} 360^{\circ}$ Tool were calculated

\subsection{Scoring Procedure of the Ei $360^{\circ}$ Tool}

Scoring procedure is a procedure to follow for scoring the questions of the items by the user. The constructors have developed a scoring procedure and its description is given in Table 4 (statements on which more than one response is given or no response given are scored zero marks)

Table 4. Scoring Method of Ei360 ${ }^{\circ}$ Tool

\begin{tabular}{|c|c|c|c|c|c|c|}
\hline \multirow{2}{*}{ S.N } & \multirow{2}{*}{ Type of Statement } & \multicolumn{5}{|c|}{ Scores } \\
\cline { 3 - 7 } & & Always & Usually & Some times & Rarely & Never \\
\hline 1 & Positive & 4 & 3 & 2 & 1 & 0 \\
\hline 2 & Negative & 0 & 1 & 2 & 3 & 4 \\
\hline
\end{tabular}

Based on the above procedure, the total scores for each student and their teachers, peers and parent were obtained. Maximum score of the tool is 248 and minimum is 0 .

Two items for self-awareness and trust worthiness of Ei $360^{\circ}$ Tool are given in Table 5a, Table 5b, Table 5c, and Table 5d. 
Table 5a. Self View Sub- Scale of Ei360 ${ }^{\circ}$ Tool

\begin{tabular}{|c|l|c|c|c|c|c|}
\hline \multirow{2}{*}{ S.N } & \multirow{2}{*}{ Statement } & \multicolumn{4}{|c|}{ Responses } \\
\cline { 5 - 7 } & & Always & Usually & Sometimes & Rarely & Never \\
\hline 1 & I recognize how my thoughts affect behaviors. & & & & & \\
\hline 2 & I accept my mistake pointed by others & & & & & \\
\hline
\end{tabular}

Table 5b. Peer View Sub- Scale of Ei $360^{\circ}$ Tool

\begin{tabular}{|c|l|c|c|c|c|c|}
\hline \multirow{2}{*}{ S.N } & \multirow{2}{*}{ My Friend Name:............................... } & \multicolumn{4}{|c|}{ Responses } \\
\cline { 5 - 7 } & & Always & Usually & Sometimes & Rarely & Never \\
\hline 1 & He/ She recognize how his/ her thoughts affect behaviors. & & & & & \\
\hline 2 & He/ She accepts my mistake pointed by others & & & & & \\
\hline
\end{tabular}

Table 5c. Teachers' View Sub- Scale of Ei360 ${ }^{\circ}$ Tool

\begin{tabular}{|c|l|c|c|c|c|c|}
\hline \multirow{2}{*}{ S.N } & \multirow{2}{*}{ My Class Student Name:........................... } & \multicolumn{5}{|c|}{ Responses } \\
\cline { 5 - 7 } & & Always & Usually & Sometimes & Rarely & Never \\
\hline 1 & He/ She recognize how his/ her thoughts affect behaviors. & & & & & \\
\hline 2 & He/ She accepts his/ her mistake pointed by others. & & & & & \\
\hline
\end{tabular}

Table 5d. Parents View Sub- Scale of Ei360 ${ }^{\circ}$ Tool

\begin{tabular}{|c|c|c|c|c|c|c|}
\hline \multirow{2}{*}{ S.N } & My Son/ Daughter Name:........................... & \multicolumn{5}{|c|}{ Responses } \\
\cline { 5 - 7 } & & Always & Usually & Sometimes & Rarely & Never \\
\hline 1 & He/ She recognize how his/ her thoughts affect behaviors. & & & & & \\
\hline 2 & He/ She accepts his/ her mistake pointed by others & & & & & \\
\hline
\end{tabular}

\section{Qualities of the Ei360 ${ }^{\circ}$ Tool}

The successiveness of the measuring tool is highly depends on the qualities of the tool such as validity, reliability and usability. The following are the qualities of the tool.

\subsection{Reliability of the Ei $360^{\circ}$ Tool}

The reliability of the sub-scales of Ei $360^{\circ}$ Tool was found by using test-retest method, split half method and internal consistencies method. The reliability values of the
Ei360 ${ }^{\circ}$ Tool were calculated and shown in Table 6.

In this, the calculated reliability values are all in high and it represented as the Ei $360^{\circ}$ Tool has high stability and consistency.

\subsection{Validity of the Ei $360^{\circ}$ Tool}

It is always related to the specific objectives or purpose of the test. It is simply called as "the degree of excellence in measurement". The following validities were found against Ei $360^{\circ}$ Tool. The description of the validities are given in Table 7.

Table 6. Reliability Values of Ei360 ${ }^{\circ} \mathrm{Tool}$

\begin{tabular}{|c|c|c|c|c|c|c|c|c|}
\hline \multirow{3}{*}{ SN } & \multirow{3}{*}{$\begin{array}{l}\text { Sub Scales of Ei } 360^{\circ} \\
\text { Tool }\end{array}$} & \multicolumn{7}{|c|}{ Reliability Statistics } \\
\hline & & \multirow[b]{2}{*}{$\begin{array}{l}\text { Sample } \\
\text { size }\end{array}$} & \multirow[b]{2}{*}{$\begin{array}{l}\text { Cronbach's } \\
\text { Alpha }\end{array}$} & \multicolumn{2}{|c|}{ Spearman brown coefficient } & \multirow[b]{2}{*}{$\begin{array}{l}\text { Gutterman Split half } \\
\text { coefficient }\end{array}$} & \multicolumn{2}{|c|}{ Test re test } \\
\hline & & & & $\begin{array}{l}\text { Equal } \\
\text { length }\end{array}$ & $\begin{array}{l}\text { Unequal } \\
\text { length }\end{array}$ & & $\begin{array}{l}\text { Sample } \\
\text { Size }\end{array}$ & $\mathrm{r}$ \\
\hline 1 & Self & 100 & 0.98 & 0.94 & 0.94 & 0.94 & 50 & 0.93 \\
\hline 2 & Teachers view & 100 & 0.97 & 0.91 & 0.91 & 0.89 & 50 & 0.90 \\
\hline 3 & Peers view & 100 & 0.97 & 0.94 & 0.94 & 0.93 & 50 & 0.92 \\
\hline 4 & Parents view & 100 & 0.98 & 0.94 & 0.94 & 0.93 & 50 & 0.91 \\
\hline
\end{tabular}

Table 7. Validity Values of Ei360 ${ }^{\circ} \mathrm{Tool}$

\begin{tabular}{|c|l|c|}
\hline SN & Methods of Validity & Values \\
\hline 1 & $\begin{array}{l}\text { Face Validity } \\
\text { Face Validity for the items constructed by the constructors was deliberated by sending the tool the subject experts and by } \\
\text { subsequent improvements suggested by the experts. }\end{array}$ & - \\
\hline 2 & $\begin{array}{l}\text { Content Validity } \\
\text { Content validity for the items constructed by the constructors was deliberated by sending the tool the subject experts and } \\
\text { suggested by the experts. The content validity ratio of Ei360 }{ }^{0} \text { Tool lies between }(\mathrm{CVR}=(\mathrm{Ne}-\mathrm{N} / 2) /(\mathrm{N} / 2))\end{array}$ & 1.25 to 6.5 \\
\hline 3 & $\begin{array}{l}\text { Construct Validity } \\
\text { Construct validity for the items calculated by the constructors, the construct validity values of Ei360 } 0^{0} \text { Tool lies between }\end{array}$ & 1.83 to 4.88 \\
\hline 4 & $\begin{array}{l}\text { Concurrent validity } \\
\text { Correlation between the Emotional Intelligence Scale (Anukool Hyde et al.,) and Ei360 } 0^{0} \text { Tool is self-administered. }\end{array}$ & 0.97 \\
\hline 5 & $\begin{array}{l}\text { Intrinsic Validity } \\
\text { Intrinsic validity for the sub scales of Ei360 }{ }^{0} \text { Tool calculated, the value lies between }\end{array}$ & 0.94 to 0.99 \\
\hline
\end{tabular}


In this, the calculated Validity values are all in high and it is conclude as the $\mathrm{Ei} 360^{\circ}$ Tool has validity.

\subsection{Norms of the Ei360 ${ }^{\circ}$ Tool}

The constructors have computed $\mathrm{Z}$ score Norms for the tool. The Z-Score norms of the each sub-scales is given Table 8. Following formula are used to find $\mathrm{Z}$-scores of each scale.

Table 8. Z Norms of Ei $360^{\circ}$ Tool

\begin{tabular}{|c|l|c|l|}
\hline S.No & Range of Z scores & Grade & Level of Emotional Intelligence \\
\hline 1 & 2.15 and Above & A & Extremely high \\
\hline 2 & 1.3 to 2.14 & B & High \\
\hline 3 & 0.45 to 1.29 & C & Above average \\
\hline 4 & -0.44 to 0.44 & D & Average \\
\hline 5 & -0.45 to -1.29 & E & Below average \\
\hline 6 & -1.3 to -2.14 & F & Low \\
\hline 7 & -2.15 and Below & G & Extremely low \\
\hline
\end{tabular}

Overall View $\left(\overline{\mathrm{X}}_{\text {Tot }}\right)=\frac{(R 1+R 2+R 3+R 4)}{4}$

$Z_{O L V}=\frac{\overline{\mathbf{X}}_{T o t}-\overline{\mathrm{X}}_{O L V}}{\sigma_{\mathrm{OLV}}}$

Self View $Z_{S V}=\frac{R_{1}-\overline{\mathrm{X}}_{S V}}{\sigma_{S V}}$

Teacher's View $Z_{T V}=\frac{R_{2}-\overline{\mathrm{X}}_{T V}}{\sigma_{T V}}$

Parent's View $Z_{P V}=\frac{R_{3}-\overline{\mathrm{X}}_{O V}}{\sigma_{O V}}$

Peer's View $Z_{P E V}=\frac{R_{4}-\overline{\mathrm{X}}_{O V}}{\sigma_{O V}}$

Where

R1 -Individual total Scores in Self-view Sub Scale of Ei $360^{\circ}$ Tool

R2 -Individual total Scores in Teachers-view Sub Scale of Ei360 ${ }^{\circ}$ Tool

R3 -Individual total Scores in Peers-view Sub Scale of Ei $360^{\circ}$ Tool

R4 -Individual total Scores in Parents-view Sub Scale of Ei360 ${ }^{\circ}$ Tool

$\bar{X}$ - Normalized Mean value of respective scale from the Table 9

$\sigma$-Normalized Mean value of respective scale from the Table 9

Table 9. Normalized Mean and Standard Deviation Scores for Ei360 ${ }^{\circ}$ Tool

\begin{tabular}{|c|l|c|c|}
\hline \multirow{2}{*}{ S.No } & \multirow{2}{*}{ Views } & \multicolumn{2}{|c|}{ Normalized Scores } \\
\cline { 3 - 4 } & & Mean $(\overline{\mathrm{X}})$ & $\begin{array}{c}\text { Standard } \\
\text { Deviation (o) }\end{array}$ \\
\hline 01. & Teacher's View (TV) & 113.79 & 41.26 \\
\hline 02. & Self View (SV) & 135.64 & 45.93 \\
\hline 03. & Parent's View (PV) & 115.25 & 42.27 \\
\hline 04. & Peer's View (PEV) & 116.99 & 43.44 \\
\hline
\end{tabular}

\section{Analysis of Correlation of the Sub-Scales of Ei360 ${ }^{\circ}$ Tool}

Correlation analysis is used to find the relationship level between the variables. The following Figure 2 shows the correlation values of sub-variables of Ei $360^{\circ}$ Tool. $(\mathrm{N}=100)$.

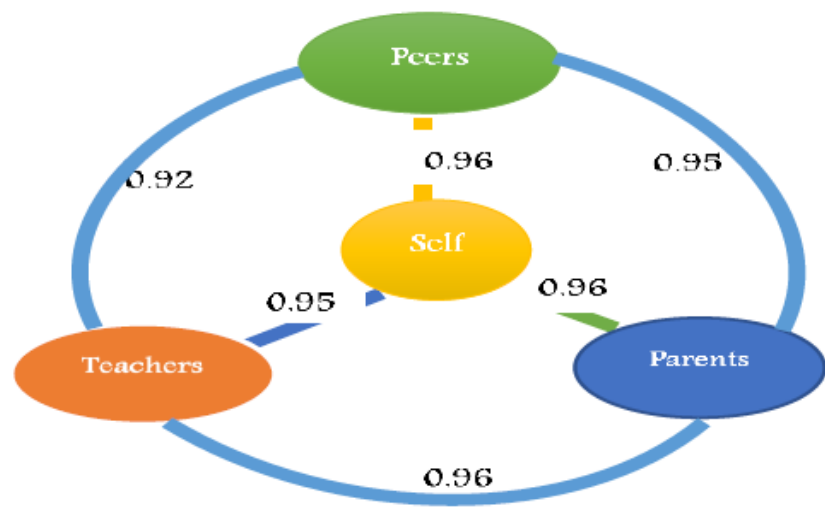

Figure 2. Correlation among the Sub Scales of Ei $360^{\circ} \mathrm{Tool}$

With reference of the Figure 2 it is evident that the correlation between the sub-groups such as self-teachers, self-peers, self-parents, parents-peers, parents-teachers, and peer-teachers are 0.95, 0.96, 0.96, 0.95, 0.96 and 0.92 respectively. In these, the $r$ values are high which is significant at 0.01 levels. It means that the preciseness of measurement of EI by using Peers View Tool, Teacher view Tool and parents view tools are same as Self tool of Ei.

\section{Conclusion}

The Emotional Intelligence $360^{\circ}$ Tool (Ei360 $0^{\circ}$ Tool) has been constructed and standardized by the tool constructors. It can be used to measure full circle Ei of a person.

\section{References}

[1] Mayer, J. D., Caruso, D. R., \& Salovey, P. Multi-Emotional intelligence meets traditional standards for on intelligence. Health Systems, Toronto, (1999).

[2] Bar-On, R. The emotional quotient inventory, EQ-I: Technical manual. Toronto: Multi Health, (1997).

[3] Murugesan, K., and Srinivasan, P. How to construct Ei360 ${ }^{\circ}$ tool. APH publication, New Delhi. (2017), 72-73.

[4] Goleman D. Working with emotional intelligence, Bantom Books, New York, (1998).

[5] Srinivasan, P. and Murugesan, K., Emotional Intelligence Scale (Situational). National Psychological Corporation, Agra (2013). 2-3.

[6] Murugesan, K., and Srinivasan, P. Standardization of EI Scale. APH publication, New Delhi. (2017), 1-2.

[7] Richard Lepsinger and Anntoinette D.Lucia. The art and science of 360 degree feedback. Jossey-Boss, San Francisco, (2009), From www.josseyboss.com.

[8] John W. Fleenor., Sylvester Taylor and Caraig Chappelow Leveraging the Impact of 360-degree Feedback, Pfeiffer. San Francisco, (2008).

[9] C Turkel. Feemale leaders 360 degree Catherine self-perception Accuracy for leadership competencies and skills. (2008). 
[10] Lashe, C,H. A quantitative approach to content validity. Personal psychology. (1975), 24(4), 563-575.

[11] Allen L Edward. Techniques of attitude scale construction, Appleton Century Crofts Inc, New york, 1957, 153-153.
[12] Anukool Hyde, Sanjyot Pethe and Upinder Dhar, Emotional Intelligence Scale. National Psychological Corporation, Agra (2002). 